\title{
Biological impact of different ventilatory strategies during open abdominal surgery in a rat model
}

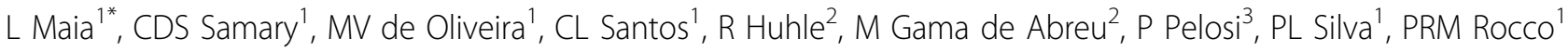 \\ From ESICM LIVES 2015 \\ Berlin, Germany. 3-7 October 2015
}

\begin{abstract}
Introduction
234 million major surgical procedures are performed worldwide every year. It has been shown that a ventilator strategy with low tidal volume $\left(\mathrm{V}_{\mathrm{T}}\right)$, high positive endexpiratory pressure (PEEP) and recruitment maneuvers (RM)s compared to low $\mathrm{V}_{\mathrm{T}}$ and low PEEP without RM did not protect against postoperative pulmonary complications [1]. So far, no study has evaluated the biological impact of these ventilator strategies in lung tissue during open abdominal surgery. We hypothesized that low $\mathrm{V}_{\mathrm{T}}$ and low PEEP without RM may result in less biological impact in lung tissue compared to a ventilator strategy with low $\mathrm{V}_{\mathrm{T}}$, high PEEP and RMs.
\end{abstract}

\section{Objective}

To evaluate the impact of different ventilator strategies on respiratory system mechanics and biological parameters during open abdominal surgery in rats.

\section{Methods}

28 male Wistar rats $(394 \pm 60 \mathrm{~g})$ were anesthetized, paralyzed, and mechanically ventilated. After baseline data collection, a laparotomy with bowel manipulation was performed. After this, animals were randomly assigned to one of four groups ( $n=7$ /group): 1 ) moderate PEEP $\left(3 \mathrm{cmH}_{2} \mathrm{O}\right)$, low $\mathrm{V}_{\mathrm{T}}(7 \mathrm{~mL} / \mathrm{kg})$, and $\mathrm{RM}$ [continuous positive airway pressure $\left(30 \mathrm{cmH}_{2} \mathrm{O}, 30 \mathrm{~s}\right)$ every hour; 2$)$ high PEEP $\left(6 \mathrm{cmH}_{2} \mathrm{O}\right)$, low $\mathrm{V}_{\mathrm{T}}(7 \mathrm{~mL} / \mathrm{kg})$ and $\mathrm{RMs}$ (at the beginning and at the end of the experiment]; 3) low PEEP $\left(1 \mathrm{cmH}_{2} \mathrm{O}\right)$, low $\mathrm{V}_{\mathrm{T}}(7 \mathrm{~mL} / \mathrm{kg})$ without RMs; 4$)$ low PEEP $\left(1 \mathrm{cmH}_{2} \mathrm{O}\right)$, high $\mathrm{V}_{\mathrm{T}}(14 \mathrm{~mL} / \mathrm{kg})$ without RMs. All animals were mechanically ventilated for four hours. Respiratory system and lung elastances ( $\mathrm{E}_{\mathrm{RS}}$ and $\mathrm{E}_{\mathrm{L}}$, respectively), peak airway pressure (Ppeak,RS), peak transpulmonary pressure $($ Ppeak,L), and blood gas analysis were evaluated every hour. At the end of the experiment, lungs were removed for molecular biology analysis (gene expression of biological markers associated with inflammation (interleukin (IL)-6, damage inflicted pulmonary stretch (amphiregulin) [2], and fibrogenesis (type III procollagen (PCIII))).

\section{Results}

All animals improved oxygenation during the time course of the experiment regardless of ventilator strategy. $\mathrm{E}_{\mathrm{RS}}$, $\mathrm{E}_{\mathrm{L}}$, Ppeak, $_{\mathrm{RS}}$, and Ppeak,,$_{\mathrm{L}}$ were lower in groups 1 and 2 (submitted to RMs) compared to groups 3 and 4 (no RMs) after 4 hours mechanical ventilation. IL- 6 expression increased in all groups independent of the ventilator strategy. Amphiregulin expression was more reduced in group 3 (low PEEP $\left(1 \mathrm{cmH}_{2} \mathrm{O}\right)$, low $\mathrm{V}_{\mathrm{T}}(7 \mathrm{~mL} / \mathrm{kg}$ ) without $\mathrm{RMs}$ ) compared to other groups. PCIII mRNA expression was more increased in group 4 (low PEEP $\left(1 \mathrm{cmH}_{2} \mathrm{O}\right)$, high $\mathrm{V}_{\mathrm{T}}$ $(14 \mathrm{~mL} / \mathrm{kg})$ without RMs) than other groups.

\section{Conclusion}

Even though groups ventilated to low $\mathrm{V}_{\mathrm{T}}$, moderate and high PEEP levels, and submitted to RMs improved lung function, they were associated with higher amphiregulin expression. Based on functional and molecular parameters, an intraoperative protective ventilation strategy should include a low $\mathrm{V}_{\mathrm{T}}$ and low PEEP, without RM.

\section{Grant Acknowledgment \\ CNPq, FAPERJ, CAPES, PRONEX}

\section{Authors' details}

${ }^{1}$ Universidade Federal do Rio de Janeiro, Rio de Janeiro, Brazil. ${ }^{2}$ Dresden University of Technology, Dresden, Germany. ${ }^{3}$ University of Genoa, Genoa, Italy. 


\section{References}

1. PROVE Network Investigators for the Clinical Trial Network of the European Society of Anaesthesiology, Hemmes SN, Gama de Abreu M, Pelosi P, Schultz MJ: High versus low positive end-expiratory pressure during general anaesthesia for open abdominal surgery (PROVHILO trial): a multicentre randomised controlled trial. Lancet 2014, 384(9942):495-503.

2. Dolinay T, Kaminski N, Felgendreher M, Kim HP, Reynolds P, Watkins SC, et al: Gene expression profiling of target genes in ventilator-induced lung injury. Physiol Genomics 2006, 26(1):68-75.

doi:10.1186/2197-425X-3-S1-A568

Cite this article as: Maia et al:: Biological impact of different ventilatory strategies during open abdominal surgery in a rat model. Intensive Care Medicine Experimental 2015 3(Suppl 1):A568.

\section{Submit your manuscript to a SpringerOpen ${ }^{\mathcal{O}}$ journal and benefit from:}

- Convenient online submission

- Rigorous peer review

- Immediate publication on acceptance

- Open access: articles freely available online

- High visibility within the field

- Retaining the copyright to your article

Submit your next manuscript at $\gg$ springeropen.com 